\title{
A REGULAMENTACÃO DA BASE DE DADOS GENÉTICOS PARA FINS DE PERSECUCÃO CRIMINAL NO BRASIL: REFLEXÕES ACERCA DO USO FORENSE DO DNA ${ }^{1}$
}

THE REGULATION OF THE GENETIC DATABASE FOR THE PURPOSES OF CRIMINAL PROSECUTION IN BRAZIL: REFLECTIONS ON THE USE OF DNA FORENSICS

\author{
LA REGLAMENTACIÓN DE LA BASE DE DATOS GENÉTICOS PARA FINES DE PERSECUCIÓN \\ CRIMINAL EN BRASIL: REFLEXIONES ACERCA DEL USO FORENSE DEL ADN
}

Taysa Schiocchet ${ }^{2}$

\begin{abstract}
RESUMO
É preciso considerar a complexidade e o necessário imbrincamento dos diversos campos do conhecimento envolvidos na criação e na gestão dos denominados bancos de DNA, inclusive para fins de persecução criminal. Diante da aprovação da Lei 12.654/2012, que regulamenta a utilização dos bancos de perfis genéticos na esfera criminal no Brasil, o presente artigo visa identificar e analisar, com base no sistema jurídico brasileiro, os possíveis riscos e benefícios em termos de direitos e garantias fundamentais que acompanham a utilização tanto do DNA individualmente considerado, quanto dos bancos de perfis genéticos para fins de persecução. A metodologia de trabalho consistiu, basicamente, na pesquisa bibliográfica e documental sobre o tema, a partir de uma perspectiva interdisciplinar. Como resultado, apresenta-se um estudo sistematizado acerca dos reflexos jurídicos da utilização de um banco de perfis genéticos para fins de persecução criminal no Direito brasileiro, de modo a subsidiar os debates sobre a problemática, bem como as tomadas de decisão no campo legislativo, de política criminal e de segurança pública.
\end{abstract}

PALAVRAS-CHAVE: Bancos de Perfis Genéticos. Biodireito. Informação genética humana. Lei 12.654/2012. Direitos fundamentais.

\section{ABSTRACT}

It is necessary to consider the complexity and the necessary overlapping of the various fields involved in the creation and management of the so-called DNA banks, including for purposes of criminal prosecution. In light of the approval of Law 12.654/2012, which regulates the use of genetic profile banks for purposes

1 Este artigo apresenta os resultados parciais de algumas pesquisas realizadas anteriormente e em curso. Dentre elas, destaca-se a principal, realizada entre 2011 e 2012 e vinculada ao projeto intitulado "Bancos de perfis genéticos para fins de persecução criminal", financiado pelo Programa das Nações Unidas para o Desenvolvimento (PNUD) em parceria com a Secretaria de Assuntos Legislativos do Ministério da Justiça (SAL/MJ), junto ao programa Pensando o Direito. Além disso, esta pesquisa obteve financiamento tanto da Fundación Carolina (2011/2012) por meio do Programa para professores brasileiros para estudos pós-doutorais sobre o tema na Universidad Autónoma de Madrid/UAM, quanto do CNPq/CAPES, por meio da Chamada n. 07/2011, cujo projeto de pesquisa encontra-se atualmente em andamento. Alguns destes resultados também podem ser lidos em: Schiocchet (2011 e 2009).

2 Doutora em Direito pela UFPR, com período de pesquisas doutorais na Université Paris I - Panthéon Sorbonne e pós-doutorais na Universidad Autónoma de Madrid. Professora do Programa de Pós-graduação em Direito (Mestrado e Doutorado) da UNISINOS, São Leopoldo - Rio Grande do Sul. Líder do Grupo de Pesquisa BioTecJus (Direito, tecnociência e biopolítica: a vida entre as fronteiras do corpo e vulnerabilidade).E-mail: taysa_sc@hotmail.com 
of criminal prosecution in Brazil, this article aims to identify and analyze, based on the Brazilian legal system, the possible risks/benefits, in terms rights and fundamental safeguards, that accompany the use of an individual genetic profile, and also of the genetic profile banks, for purposes of criminal prosecution. The work method basically consisted of bibliographic and documentary research on the theme, through an interdisciplinary perspective. As results, a systematized study is presented on the legal consequences of the use of genetic profile banks in Brazilian law, in order to support discussions about this subject, as well as decision-making in the legislative field, on matters of criminal politics and public safety.

KEY WORDS: Genetic profile banks. Biolaw. Human genetic information. Law 12.654/2012. Fundamental rights.

\section{RESUMEN}

Es preciso considerar la complejidad y la necesaria imbrincación de los diversos campos del conocimiento involucrados en la creación y en la gestión de los denominados bancos de ADN, inclusive para fines de persecución criminal. Ante la aprobación de la Ley 12.654/2012, que reglamenta la utilización de los bancos de perfiles genéticos en la esfera criminal en Brasil, el presente artículo tiene el propósito de identificar y analizar, en base al sistema jurídico brasileño, los posibles riesgos y beneficios en términos de derechos y garantías fundamentales que acompañan la utilización tanto del ADN individualmente considerado, como de los bancos de perfiles genéticos para fines de persecución. La metodología de trabajo consistió, básicamente, en una investigación bibliográfica y documental sobre el tema a partir de una perspectiva interdisciplinaria. Como resultado se presenta un estudio sistematizado acerca de los reflejos jurídicos de la utilización de un banco de perfiles genéticos para fines de persecución criminal en el Derecho brasileño, para dar fundamento a los debates sobre la problemática, así como a las tomas de decisión en el campo legislativo, de política criminal y de seguridad pública.

PALABRAS CLAVE: Bancos de Perfiles Genéticos. Bioderecho. Información genética humana. Ley 12.654/2012. Derechos fundamentales.

\section{INTRODUÇÃO}

As descobertas na área da genética humana são consideravelmente amplas e sua aplicação técnica cada vez mais diversificada, não apenas na área da identificação civil e penal, mas também no contexto da pesquisa e da medicina. Os resultados obtidos no campo do diagnóstico genético são significativos e seu principal benefício consiste na possibilidade de prevenir doenças ou evitar o seu desenvolvimento, já que é possível descobrir precocemente a presença de genes e cromossomos alterados, os quais são responsáveis por inúmeras enfermidades genéticas. Com os avanços das biotecnologias nos últimos anos, mais precisamente com a possibilidade de estabelecer a função e regulação dos genes, a pesquisa e a medicina são efetivamente as áreas que contam com um arcabouço normativo mais avançado em detrimento de outras, como a do Direito Penal.

No entanto, o vácuo normativo, existente em diversos países, não é óbice para a criação de bancos de perfis genéticos para fins de persecução criminal. Ao contrário, a criação dos referidos bancos acaba servindo como força propulsora à elaboração normativa. No Brasil não foi diferente. Os anos de 2011 e 2012, foram decisivos para a aprovação da Lei n 12.654 de 28 de maio de $2012^{3}$, que autoriza a coleta de material genético para fins de persecução criminal e regulamenta o banco de perfis genéticos para esse mesmo fim, nos seguintes termos:

(...) 'Art. $5^{\circ}$-A. Os dados relacionados à coleta do perfil genético deverão ser armazenados em banco de dados de perfis genéticos, gerenciado por unidade oficial de perícia criminal.

3 Com vacatio legis de 180 dias. 
$\S 1$ 을 informações genéticas contidas nos bancos de dados de perfis genéticos não poderão revelar traços somáticos ou comportamentais das pessoas, exceto determinação genética de gênero, consoante as normas constitucionais e internacionais sobre direitos humanos, genoma humano e dados genéticos.

§ 2ㅇ Os dados constantes dos bancos de dados de perfis genéticos terão caráter sigiloso, respondendo civil, penal e administrativamente aquele que permitir ou promover sua utilização para fins diversos dos previstos nesta Lei ou em decisão judicial.

$\S 3$ 3 As informações obtidas a partir da coincidência de perfis genéticos deverão ser consignadas em laudo pericial firmado por perito oficial devidamente habilitado.'

'Art. 70-A. A exclusão dos perfis genéticos dos bancos de dados ocorrerá no término do prazo estabelecido em lei para a prescrição do delito.'

'Art. 7-B. A identificação do perfil genético será armazenada em banco de dados sigiloso, conforme regulamento a ser expedido pelo Poder Executivo.'

$(\ldots)$

'Art. 9०-A. Os condenados por crime praticado, dolosamente, com violência de natureza grave contra pessoa, ou por qualquer dos crimes previstos no art. 1ㅇ da Lei no 8.072 , de 25 de julho de 1990 , serão submetidos, obrigatoriamente, à identificação do perfil genético, mediante extração de DNA - ácido desoxirribonucleico, por técnica adequada e indolor.

$\S 1^{\circ}$ A identificação do perfil genético será armazenada em banco de dados sigiloso, conforme regulamento a ser expedido pelo Poder Executivo.

$\S$ 2ㅇ A autoridade policial, federal ou estadual, poderá requerer ao juiz competente, no caso de inquérito instaurado, o acesso ao banco de dados de identificação de perfil genético. (grifado)

A despeito da presença maciça das biotecnologias e das pesquisas genéticas no país, inclusive forense, bem como da proliferação de documentos normativos no plano internacional, a população brasileira é particularmente afetada pela criminalidade e pelos reflexos de um sistema jurídico debilitado e titubeante. A incipiência e mesmo imaturidade jurídica sobre o tema no Brasil, tanto na literatura quanto na regulamentação do Direito estatal positivo, deve-se ao impacto recente das biotecnologias na temporalidade e na espacialidade do Direito, bem como nas categorias jurídicas clássicas.

É sabido que a criação de bancos genéticos ocorre com finalidades distintas, no entanto é preciso considerar a complexidade e o necessário imbricamento dessas finalidades, especialmente na criação e na gestão dos biobancos, pois há um fator comum anterior a todos os bancos que é o acesso ao material biológico ou genético humano. Inclusive, quando da criação de bancos de perfis genéticos para fins de persecução criminal.

Levando em consideração esses pressupostos, o presente artigo tem como objetivo identificar e analisar, com base no sistema jurídico brasileiro e no direito comparado, os possíveis riscos/benefícios, bem como os limites/possibilidades à utilização do DNA para fins forenses e, mais concretamente, a regulamentação de bancos de perfis genéticos para fins de persecução criminal, de forma a respeitar os direitos e as garantias fundamentais do cidadão, seja em termos de efetiva tutela jurisdicional, seja em termos de privacidade e autodeterminação corporal e informacional.

\section{DA COLETA DO MATERIAL BIOLÓGICO AO ARMAZENAMENTO DO PERFIL GENÉTICO}

Primeiramente, convém destacar, especialmente àqueles que não estão familiarizados com o tema, que existe uma diferença fundamental entre material biológico ou genético e perfil genético. O material biológico, neste caso o humano, pode consistir em uma amostra de sangue, saliva, bulbo capilar, entre outros, a partir do qual se fará a análise para a extração do chamado "perfil genético".

A Figura 1 mostra uma imagem de um perfil genético após análise do material genético/ biológico. 

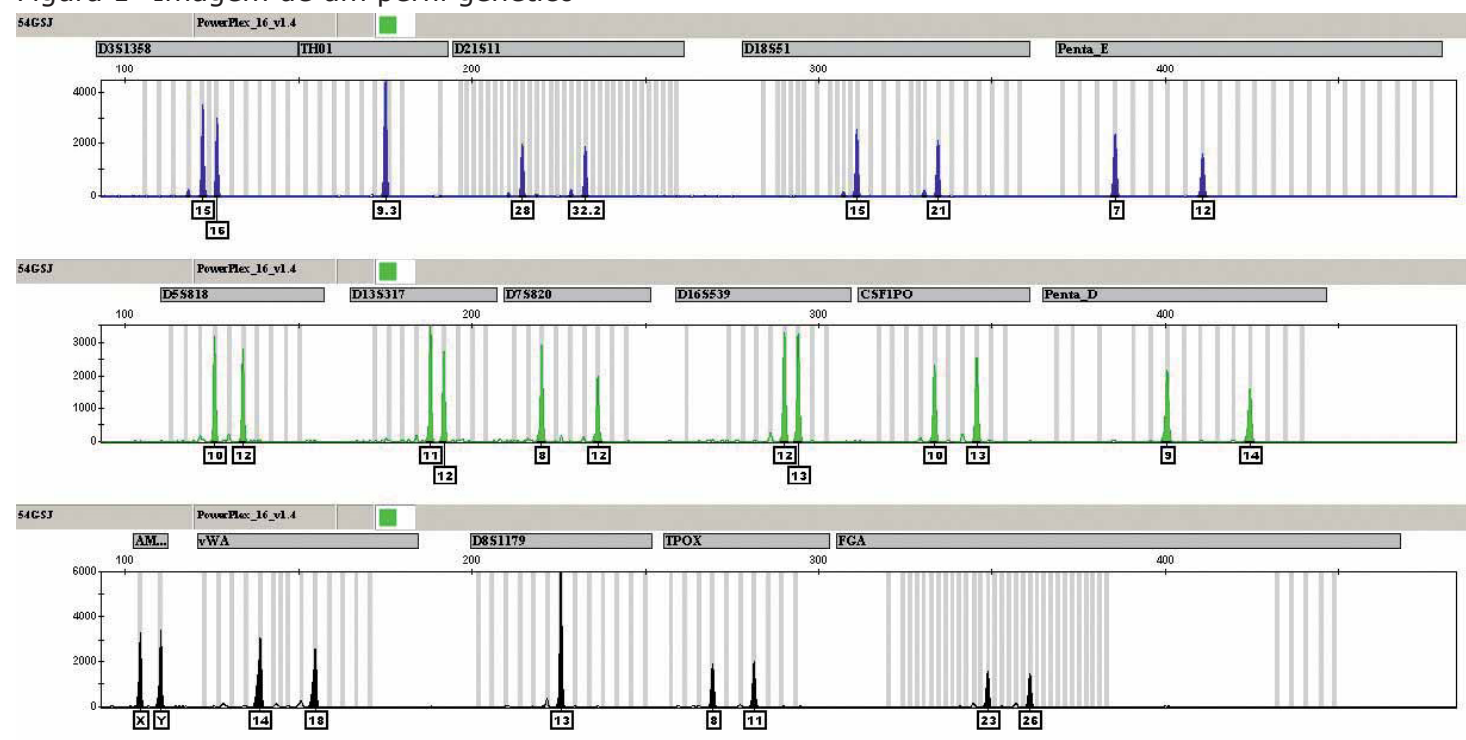

A técnica de coleta do material genético por meio do suabe (swab, em inglês) é considerada não invasiva, nos termos da Declaração Internacional sobre Dados Genéticos Humanos 5 . Apesar de não haver danos à integridade física, isso não significa, entretanto, que tal coleta não possa atingir outros direitos e garantias, como a autodeterminação corporal e informacional, especialmente quando a técnica de coleta for compulsória.

Uma amostra de DNA possui regiões ditas codificantes e não codificantes. Os denominados perfis genéticos constituem uma parte das informações contidas na amostra de DNA e são extraídos de regiões ditas não codificantes. Os testes que visam determinar as impressões genéticas ou perfis genéticos são destinados, em geral, à identificação de uma pessoa no âmbito criminal em função da distribuição de marcadores genéticos polimórficos. As características genéticas nas regiões codificantes seriam, a priori, conservadas e utilizadas apenas para fins médicos ou de investigação científica, enquanto os perfis genéticos utilizados pela polícia e pela Justiça identificariam, segundo os cientistas, apenas os marcadores sexuais e sequências teoricamente não codificantes.

Em síntese, portanto, as informações contidas no material genético de um indivíduo podem dizer respeito a aspectos físico do mesmo. Isso depende de onde essa informação é retirada. Nem todas as regiões do DNA possuem informações sobre características físicas da pessoa-fonte. Segundo Lima (2008, p. 9), "mais de 95\% do genoma não trazem informação alguma que se converterá em características físicas. Foi por muito tempo chamado de junk DNA (DNA lixo, em inglês)". Isso porque apenas $5 \%$ do DNA teriam influência em características físicas, ainda que atualmente existam novas descobertas acerca da parcela junk do DNA, como uma utilidade na estabilidade da molécula.

Nesta esteira, Jacques e Minervino ${ }^{6}$ afirmam que:

(...) é preciso que fique clara a distinção entre o DNA (uma molécula que contém muitas informações) e o perfil genético (uma pequena informação extraída do DNA). O DNA como um todo pode, realmente, revelar muitas informações sensíveis, como a propensão a doenças, entre outras. O perfil genético, entretanto, é incapaz de revelar qualquer característica física ou de saúde. A única aplicação do perfil genético é a individualização. Infelizmente, devido ao parco entendimento público sobre a ciência e a tecnologia envolvidos nesta questão, muitas pessoas são levadas a acreditar que o perfil genético tem muito mais informações do que ele realmente tem.

Em que pese a afirmação de que haveria uma clara distinção entre a parte codificante e não codificante do DNA, é preciso levar em consideração que essa taxionomia e distinção é resultado 4 JACQUES, Guilherme Silveira; MINERVINO, Aline Costa. Aspectos éticos e legais dos bancos de dados de perfis genéticos. Revista Pericia Federal, Brasília. Junho/2007-agosto/2008, ano IX, n² 26, p. 18.

5 UNITED NATIONS EDUCATIONAL, SCIENTIFIC AND CULTURAL ORGANIZATION (UNESCO). Declaração internacional sobre dados genéticos humanos. Paris: Unesco, 2003.

6 JACQUES, Guilherme Silveira; MINERVINO, Aline Costa. Aspectos éticos e legais dos bancos de dados de perfis genéticos. p. 19. 
do estado atual do conhecimento científico, o qual tende a apresentar novas descobertas. Nesse sentido, muitos biólogos têm demonstrado que essa distinção categórica é falaciosa, pois mesmo a parte não codificante do DNA pode apresentar informações específicas (e, portanto, sensíveis) atinentes ao sujeito analisado.

Casabona e Malanda7 lembram que o perfil genético traz informação sobre a descrição étnica do sujeito (independentemente de esta característica ter se manifestado fenotipicamente) e sobre o sexo (o que poderia revelar alguma anomalia patológica, como as trissomias, ou mesmo uma característica psicológica e social relacionada ao sexo). Além disso, não se descarta a possibilidade de que no futuro (próximo) os estudos do DNA dito não codificante aportem outros tipos de informação (como a cor dos olhos), afinal as pesquisas genéticas são recentes na história da humanidade e avançam vertiginosamente.

Contudo, é preciso enfatizar que, de qualquer modo, existe sempre a coleta da amostra de DNA que contém toda a informação genética humana - seja ela codificante ou não codificante, pequena ou não, de mera individualização genotípica ou acerca das características de saúde e comportamento - que pode ser utilizada inadequadamente, inclusive como meio de estigmatização ou discriminação. Um exemplo ocorreu nas décadas de 1960 e 1970, quando surgiu um debate acerca da propensão dos homens com um Y a mais ("síndrome XYY") a cometer crimes. "Após alguns estudos indicarem que a freqüência de homens XYY era maior em presídios do que na população em geral, os portadores de cromossomo $Y$ passaram a ser discriminados, mesmo que não apresentassem comportamento agressivo ou criminoso"s.

Corroborando esse entendimento, Casabona e Malanda ${ }^{9}$ afirmam:

(...) la disponibilidad de muestras biológicas que, como se recordó, contienen en secuencias tanto la parte codificante como no codificante del ADN, y el potencial acceso irrestricto a las mismas, legítimamente autorizado o no, supone una nueva fuente de peligro de utilización desviada o abusiva de la información sobre la salud presente o futura del individuo que contiene, lo que no ocurre en otros casos, p. ej., con las huellas dactilares, con las cuales suelen equipararse los perfiles de ADN. Por tanto, la unión indisoluble del conjunto del ADN y la necesidad de su manipulación conjunta comporta también un mayor riesgo de impunidad, a lo que se suma la dificultad de detectar la realización ilícita del análisis.

Assim sendo, qualquer dado pessoal de caráter genético deve ser considerado um dado que afeta a intimidade genética da pessoa e, portanto, deve ser protegido pelo direito fundamental à intimidade.

\section{DO SINGULAR AO COLETIVO: SOBRE A GENÉTICA DE INDIVÍDUOS E POPULAÇÕES}

A informação genética, nesses casos, será necessariamente objeto de comparação para ter algum valor científico e mesmo jurídico-probatório. Diante disso, destaca-se o caráter probabilístico dessa informação genética, por um lado, e a relação com estudos populacionais e comparativos, por outro.

Além disso, é preciso ainda levar em consideração a denominada "teoria do mosaico", segundo a qual existem dados que isoladamente não aportam informações pessoais, mas que, uma vez cruzados com outros dados, podem trazer informações que afetam a intimidade genética pessoal. Como exemplo, Casabona e Malanda ${ }^{10}$ mencionam a descoberta da existência ou da inexistência de relação parental biológica desconhecida anteriormente.

Os dados apurados e anonimizados pelos arquivos genéticos para fins criminais se limitam ao âmbito não codificado do DNA, que possibilita aos biólogos moleculares determinar a identidade da

7 CASABONA, Carlos Maria Romeo; MALANDA, Sergio Romeo. Los Identificadores del ADN en el Sistema de Justicia Penal, Revista Derecho y Proceso Penal. n²3, Arazandi, 2010. P. 62.

8 JACQUES, Guilherme Silveira; MINERVINO, Aline Costa. Aspectos éticos e legais dos bancos de dados de perfis genéticos. p. 18

9 CASABONA, Carlos Maria Romeo; MALANDA, Sergio Romeo. Los Identificadores del ADN en el Sistema de Justicia Penal. P. 63.

10 CASABONA, Carlos Maria Romeo; MALANDA, Sergio Romeo. Los Identificadores del ADN en el Sistema de Justicia Penal. p. 62. 
pessoa e possíveis relações de parentesco. De todo modo, convém lembrar que a amostra armazenada (material genético) contém todas as demais informações genéticas do indivíduo.

Por outro lado, mesmo se tratando de perfil genético (e não informação sobre características físicas) é preciso avaliar os riscos relativos ao armazenamento destas informações em um banco. Em outras palavras, é preciso avaliar a vulnerabilidade das mesmas, seja em termos de acesso (restrito a quem e controlado por quem) ou, mais especificamente, em termos de codificação (dissociação do perfil ao nome da pessoa).

Fatos como estes demonstram que o acesso à tecnologia e à informação por ela gerada pode ser utilizado - atualmente ou no futuro - de diversas maneiras, muitas vezes desconhecidas ou não previstas, inclusive de forma antiética ou ilegal. Por essa razão, incumbe ao Direito levar em consideração essas possibilidades (ainda que não desejadas) no momento da elaboração de uma legislação.

Existe uma grande diversidade de modelos de bancos e bases de dados genéticos. Os bancos de DNA podem ser conceituados como conjuntos de materiais ou dados genéticos, informatizado ou não. Em outras palavras, os bancos de DNA ou biobancos podem ser definidos como grandes coleções de material genético (amostras de DNA, células, tecidos, tumores ou órgãos) associados a dados de diversas naturezas (genéticos, médicos, biológicos, familiares, socioambientais). Já as bases de dados genéticos referem-se aos elementos genéticos já sequenciados e digitalizados.

Segundo o relatório Creation and governance of Human Genetic Research Databases da Organização de Cooperação para o Desenvolvimento Econômico (OCDE): "any collection of samples from which genetic samples can be derived and related data (e.i. genealogical, clinical, etc.) organized in a systematic way and used for purpose of research"11. No entanto, essa definição exclui as denominadas bases de dados genéticos, ou seja, os bancos de perfis genéticos para fins de persecução criminal.

Na obra intitulada "Les biobanques" ("Os biobancos"), as autoras Noiville e Bellivier (2009, p. 5) apresentam um panorama sobre a complexa realidade de "collectioner le vivant" ("colecionar o vivente"). Elas referem-se aos bancos ou aos repositórios de amostras biológicas humanas e seus respectivos dados. A terminologia é vasta: biobancos, biotecas, coleções de amostras biológicas, centros de recursos biológicos, bancos de viventes, bancos de dados genéticos, base de dados genéticos, base de dados de pesquisa em genética humana, biobancos virtuais, biorepositórios, bancos de tecidos, bancos de genes, registros. Essa diversidade terminológica denuncia a vagueza semântica dos conceitos.

No entanto, os biobancos diferenciam-se dos bancos de perfis genéticos, de modo que, segundo Noiville e Bellivier ${ }^{12}$, não é possível qualificar um banco de perfis genéticos para fins de persecução criminal como biobanco. Isso porque ele não tem finalidade terapêutica ou de pesquisa. A finalidade dos bancos de perfis genéticos é identificar, mais eficazmente, os autores de delitos, de modo a prevenir, inclusive, a reincidência. Nesse sentido, seria incorreto abarcar no conceito de biobanco também os bancos de perfis genéticos para fins de identificação criminal.

Os biobancos teriam, portanto, como características comuns: uma infraestrutura pública ou privada, o agrupamento organizado de amostras biológicas (células, tecidos, urinas, genes, fragmentos de ADN) e dados (clínicos dos pacientes, familiares ou mesmo de toda a população, dados genealógicos ou biológicos, relativos ao modo de vida) por um determinado período de tempo, com finalidade de pesquisa médica ${ }^{13}$.

Em que pese tal diferenciação conceitual, de um modo geral, os biobancos e os bancos de dados genéticos podem ser classificados a partir dos seguintes critérios: estatuto jurídico público ou privado (refere-se ao ato de criação, isto é, se foi criado por uma lei ou por contrato); finalidade (refere-se à destinação do banco e das suas amostras e dos dados armazenados), conteúdo (a depender do tipo de material ou dado armazenado); tamanho e grau de organização e, por fim, circulação das amostras e dados ao exterior ${ }^{14}$. No que se refere aos bancos de dados genéticos, é importante a tipologia com base no conteúdo e na finalidade.

11 Tradução livre: "qualquer coleção de amostras das quais podem derivar amostras genéticas e dados relacionadas (tais como genealógicos, clínicos etc.) organizados de modo sistemático e usados para fins de pesquisa" (OCDE, Creation and governance of Human Genetic Research Databases. p.34).

12 BELLIVIER, F.; NOIVILLE, C. Les biobanques. Paris: PUF, 2009. p. 6.

13 BELLIVIER, F.; NOIVILLE, C. Les biobanques. p. 6.

14 BELLIVIER, F.; NOIVILLE, C. Les biobanques. p. 35-45. 
De acordo com o conteúdo, os bancos de dados genéticos podem ser divididos em: Base de dados de identificação genética; Arquivos de DNA e Arquivos de amostras biológicas.

\begin{tabular}{|l|l|}
\hline \multicolumn{2}{|l|}{ TIPOLOGIA DOS BIOBANCOS E BANCOS DE DADOS GENÉTICOS } \\
\hline CONTEÚDO & DEFINIÇÃO \\
\hline $\begin{array}{l}\text { Dados de } \\
\text { identificação } \\
\text { genética }\end{array}$ & $\begin{array}{l}\text { Dados alfanuméricos (letras e números associados ao código de identificação de } \\
\text { uma pessoa, observando-se o princípio da dissociação). }\end{array}$ \\
\hline $\begin{array}{l}\text { Arquivos de DNA } \\
\text { Amostras de DNA, normalmente congeladas e com DNA já extraído do núcleo celular, } \\
\text { pronto para ser analisado (em suas regiões codificantes e não codificantes). }\end{array}$ \\
\hline $\begin{array}{l}\text { Arquivos de } \\
\text { amostras } \\
\text { biológicas }\end{array}$ & $\begin{array}{l}\text { Não são bancos de dados propriamente, mas de material biológico. Potencial ime- } \\
\text { diato de informação menor, pois o DNA ainda não foi extraído. }\end{array}$ \\
\hline
\end{tabular}

\title{
CONTRIBUIÇÕES NORMATIVAS DO DIREITO INTERNACIONAL DA BIOÉTICA
}

Os bancos de perfis genéticos para fins de persecução criminal necessitam do acesso ao corpo humano ou parte dele, como fonte biológica, para alcançar algum tipo de resultado. Esse acesso é, em geral, viabilizado mediante o consentimento informado da pessoa, como expressão da sua vontade. A obtenção da amostra biológica é, assim, a ponte de acesso ao corpo. Nesses casos, é preciso questionar se é devido, permitido ou proibido utilizar o mesmo enquadramento normativo da disposição corporal, realizado mediante disposição gratuita e operacionalizada pelo consentimento informado, para o campo criminal.

A Declaração Universal sobre Bioética e Direitos Humanos ${ }^{15}$, em seu artigo $9^{\circ}$, trata da privacidade e da confidencialidade ao afirmar que:

\begin{abstract}
A vida privada das pessoas em causa e a confidencialidade das informações que thes dizem pessoalmente respeito devem ser respeitadas. Tanto quanto possível, tais informações não devem ser utilizadas ou difundidas para outros fins que não aqueles para que foram coligidos ou consentidos e devem estar em conformidade com o direito internacional, e nomeadamente com o direito internacional relativo aos direitos humanos.
\end{abstract}

Ainda que a Declaração Internacional sobre Dados Genéticos Humanos ${ }^{16}$ não se aplique especificamente aos bancos de perfis genéticos para fins de persecução criminal, é importante considerar sua preocupação com o acesso e a manipulação de material e de dados genéticos humanos. Ao mesmo tempo em que aceita as diretrizes legislativas internas de Direito Penal, ela sinaliza os limites para a criação do denominado "banco de dados de DNA". Para tanto, a referida Declaração traz definições importantes, inclusive para os bancos de perfis genéticos para fins de persecução criminal.

Os dados associados a uma pessoa identificável, previstos no item IX, são fundamentais para atingir o objetivo de um banco de dados para identificação criminal, já que identificam e qualificam o doador do material genético. Porém, para evitar divulgação ilícita e garantir a proteção dos dados, o item $\mathrm{X}$ corresponde a não identificação direta da pessoa, que é feita apenas por meio de um código. Na perspectiva de um banco de dados para persecução penal, os dados irreversivelmente dissociados seriam aqueles que confrontados com outros perfis não apresentaram coincidência, conforme o item XI.

15 UNITED NATIONS EDUCATIONAL, SCIENTIFIC AND CULTURAL ORGANIZATION (UNESCO). Declaração internacional sobre dados genéticos humanos.

16 UNITED NATIONS EDUCATIONAL, SCIENTIFIC AND CULTURAL ORGANIZATION (UNESCO). Declaração internacional sobre dados genéticos humanos. 
O banco de dados genéticos identificará as pessoas suspeitas que se dispuserem a doar o material biológico, e seus dados poderão servir para fins estatísticos, ou como padrão de melhoria do sistema de base de dados. Interessante notar que o artigo 60 estabelece os padrões para a criação de bancos de dados para persecução criminal, com bases éticas, baseadas no consentimento prévio, livre, informado e expresso e, principalmente, sem coerção.

(d) Do ponto de vista ético, é imperativo que sejam fornecidas informações claras, objetivas, adequadas e apropriadas à pessoa a quem é solicitado consentimento prévio, livre, informado e expresso. Estas informações, além de fornecerem outros pormenores necessários, especificam as finalidades para as quais serão obtidos, utilizados e conservados os dados genéticos humanos e dados proteômicos da análise das amostras biológicas. Estas informações deverão se necessário, indicar os riscos e consequências em causa. Deverão igualmente indicar que a pessoa poderá retirar o seu consentimento sem coerção e que daí não deverá resultar para ela qualquer desvantagem ou penalidade ${ }^{17}$.

Como já mencionado, no campo da pesquisa e da medicina é que se explicita a regra do consentimento informado, para pessoa submetida a uma investigação ou a um diagnóstico genético, conforme artigo $8^{\circ}$ da Declaração ${ }^{18}$. Questiona-se, portanto, a extensão do consentimento ao âmbito penal e a possibilidade de sua utilização na esfera dos bancos de dados genéticos para fins criminais.

(a) O consentimento prévio, livre, informado e expresso, sem tentativa de persuasão por ganho pecuniário ou outra vantagem pessoal, deverá ser obtido para fins de recolha de dados genéticos humanos, de dados proteômicos humanos ou de amostras biológicas, quer ela seja efetuada por métodos invasivos ou não-invasivos, bem como para fins do seu ulterior tratamento, utilização e conservação, independentemente de estes serem realizados por instituições públicas ou privadas. Só deverão ser estipuladas restrições ao princípio do consentimento por razões imperativas impostas pelo direito interno em conformidade com o direito internacional relativo aos direitos humanos ${ }^{19}$

Tendo em vista a possibilidade de a prova obtida por meio do DNA contribuir para a condenação do indivíduo, é necessário que a decisão de inserção do material biológico ou perfil genético no banco de dados seja feita com o consentimento esclarecido do acusado.

\section{CONSIDERAÇÕES FINAIS}

É possível verificar que diversos países estão com seus bancos de perfis genéticos para fins de persecução criminal regulamentados. No entanto, esse panorama não se consolida sem debates contínuos acerca dos direitos envolvidos, garantidos e, eventualmente, desrespeitados.

Assim, torna-se imprescindível a discussão sobre os limites que a Constituição Federal brasileira pode apresentar, no sentido de proteção aos bens jurídicos fundamentais protegidos. Entretanto, o que se tem observado, na prática legislativa, é o recurso constante às finalidades de política criminal, sobretudo no que tange à persecução criminal, para relativizar direitos e garantias fundamentais em nome da observância e do atendimento ao direito da coletividade à segurança. Busca-se o instrumento imediatista e simbólico da lei penal como solução para os problemas de segurança pública e para os deficits do aparato do Estado no combate à criminalidade.

A própria ideia de Constituição sofreu uma mudança paradigmática: outrora o constitucionalismo liberal com ênfase na organização do Estado e na proteção de um elenco de direitos de liberdade cedeu espaço para o constitucionalismo social, em que direitos ligados à promoção da igualdade material passaram a ter assento constitucional e ocorreu uma ampliação notável das tarefas a serem desempenhadas pelo Estado no plano econômico e social20.

A promulgação da Constituição Federal de 1988 abriu para o Brasil uma nova gama de possibilidades de reestruturação social, estatal e jurídica, com a positivação de diferentes núcleos

17 UNITED NATIONS EDUCATIONAL, SCIENTIFIC AND CULTURAL ORGANIZATION (UNESCO). Declaração internacional sobre dados genéticos humanos.

18 UNITED NATIONS EDUCATIONAL, SCIENTIFIC AND CULTURAL ORGANIZATION (UNESCO). Declaração internacional sobre dados genéticos humanos.

19 UNITED NATIONS EDUCATIONAL, SCIENTIFIC AND CULTURAL ORGANIZATION (UNESCO). Declaração internacional sobre dados genéticos humanos.

20 BARROSO, Luís Roberto. Curso de direito constitucional contemporâneo: os conceitos fundamentais e a construção do novo modelo. 3. ed. São Paulo: Saraiva, 2011. p.107. 
de direitos fundamentais - individuais, coletivos e culturais, com uma profundidade como nunca ocorrera anteriormente na vida constitucional do País, estando, entre as transformações ocorridas, a edição da legislação penal.

Diferentemente do que a lógica sintática demonstra, na qual a expansão do direito e o surgimento de novas leis e normas deveria representar uma melhor e mais abrangente proteção dos bens jurídicos devido ao aumento do espectro de condutas sujeitas à incidência da lei penal, a potencial inefetividade da legislação penal pós-Constituição de 1988 é aparente pela incidência de alternativas às penas privativas de liberdade em crimes leves ou, muitas vezes, em crimes mais graves dentro do sistema jurídico brasileiro. No mesmo sentido, pode-se citar o caso do terrorismo nos países europeus, por exemplo, nos quais o que se percebe é que, segundo Meliá ${ }^{21}$, o terrorismo não é efetivamente combatido por meio de uma saturação de leis criminais, mas pelo contrário, as mesmas sobrecarregam a capacidade preventiva, realçando ainda mais a ideia de que, muitas vezes, lançam-se inúmeras regras em nosso sistema jurídico sem ao menos saber sua função e o que está sendo protegido.

É possível perceber que, apesar da crescente expansão do direito penal e o surgimento de inúmeras leis referentes a novas situações antes desconhecidas pelo ordenamento, apenas se está suprindo de forma simbólica as necessidades da sociedade no momento em que se criaram leis que, muitas vezes, não são efetivas, portanto em meio à situação da possível implementação de um banco de perfis genéticos para fins de persecução criminal, é necessário um enorme cuidado na formulação das leis referentes ao tema, para que haja assim parâmetros bem definidos quanto à sua utilização e aos seus limites impostos pelo Direito. Isso porque a legitimação do referido banco não representa uma melhor proteção e abrangência jurídica, já que, se o mesmo não for aplicado correta e cuidadosamente, não possuirá a efetividade buscada em sua idealização.

Por essas razões, somente depois de enfrentadas e superadas as discussões de ordem constitucional é possível pensar na regulamentação específica referente aos bancos de perfis genéticos para fins de persecução criminal. Dentre as questões consideradas fundamentais, destacam-se algumas delas.

Primeiramente, é imperioso analisar se é constitucional que a coleta de material genético ocorra compulsoriamente (mesmo mediante técnica não invasiva de coleta) ou se deve ser voluntariamente (mediante consentimento informado ou assentimento), tendo em vista os direitos fundamentais possivelmente afetados, dentre eles: integridade corporal (em sentido amplo), intimidade (tanto corporal quanto genética), autodeterminação informacional, presunção de inocência, direito ao silêncio e não autoincriminação, liberdade de decisão e física, liberdade religiosa, assim como a tutela judicial efetiva.

Desse questionamento, decorre a necessidade de analisar qual é a extensão ou o sentido do princípio constitucional relativo à proibição de produção probatória contra si mesmo no direito brasileiro (do ponto de vista da legislação, da jurisprudência e da doutrina), especialmente tendo em vista que o DNA nesses casos possui dupla natureza, isto é, trata-se de um ato de investigação (identificação) e, ao mesmo tempo, um ato de produção probatória (prova), ainda que probabilística e falível - convém lembrar.

Pode-se considerar este aspecto um dos maiores desafios jurídicos a ser enfrentado, isto porque a Constituição Federal brasileira (além da Convenção Interamericana de Direitos Humanos, da qual o Brasil é signatário) prevê expressamente como direito fundamental - portanto cláusula pétrea - que ninguém tem o dever de produzir prova em seu desfavor (autoincriminação), mesmo diante de uma acusação formal. Trata-se, em outras palavras, do princípio da autodefesa que integra o direito ao silêncio, o direito de não produzir provas contra si mesmo, bem como o direito de não confessar.

Além disso, do ponto de vista jurisprudencial, convém considerar a interpretação - fortemente garantista - que vem sendo dada a esse direito pelo Supremo Tribunal Federal em diversos casos, inclusive aqueles envolvendo a obrigatoriedade (ou não) do condutor de automóvel submeter-se ao teste de alcoolemia, os quais possuem - guardadas as devidas distinções - diversos aspectos em comum com a obrigatoriedade (ou não) de submeter-se ao exame de DNA (com a coleta do material biológico para extração do perfil genético).

21 MELIÁ, Manuel Cancio. Terrorism and criminal Law: the dream of prevention, the nightmare of the rule of Law. New Criminal Law Review. Califórnia. vol. 14, No. 1, 2011, p. 108-122. 
Em segundo lugar, é imperioso analisar a forma de constituição do banco, ou seja, se é adequado, ética e juridicamente, criar um banco de perfis genéticos cujas amostras coletadas originam-se de um determinado grupo da população (com base em determinados critérios, como condenado, suspeito, etc.) e, nesse caso, quais critérios de coleta de material biológico deveriam ser utilizados com base no postulado da proporcionalidade. Ou, por outro lado, se seria mais adequado criar um banco universal, com amostras de todos os cidadãos de determinado Estado, sem qualquer distinção ou critério para a realização da coleta.

Nesse sentido, cumpre analisar também em que medida a criação de um banco de perfis genéticos para fins de persecução criminal ofenderia ou restringiria direitos e garantias fundamentais, como a privacidade e a intimidade da pessoa (o que implica, por consequência, analisar a questão do armazenamento das amostras e perfis genéticos, bem como a questão da responsabilidade pela gestão do banco) e se haveria algum outro princípio ou direito constitucional que justificaria juridicamente tal relativização ou restrição aos direitos fundamentais.

Os perfis genéticos não oferecem resultados de identificação plena, absoluta (100\%) e, portanto, não são irrefutáveis, como sugerem erroneamente algumas pessoas envolvidas científica e politicamente com o tema. Em outras palavras, a genética forense não valora os resultados das análises em termos de fiabilidade absoluta, mas o menor ou maior grau de incerteza em termos de probabilidades.

Trata-se, portanto, de um resultado ou prova de probabilidade. Por essa razão, os resultados não podem ser aceitos de forma automática. Desse modo, o laudo pericial não deve mascarar fragilidades encontradas no decorrer das análises. Para esse cálculo de probabilidade, recomendase a utilização de uma fórmula de base estatística, que é o denominado Teorema de Bayes, o qual permite inserir informações adicionais ao número de polimorfismos coincidentes. Para tanto, é preciso levar em consideração quais os marcadores serão utilizados, qual a frequências dos polimorfismos na população (estudos genéticos populacionais), bem como qual é a população de referência (de determinado estado, região, país, etnia, etc.).

De fato, para que haja efetivamente um resultado mais próximo da realidade, é preciso levar em consideração dados adicionais não estatísticos que são conhecidos pelo juiz e não pelo perito. Portanto, ressalta-se, é preciso relativizar os resultados da prova genética e compreender que o poder da perícia é limitado. Isso implica para os operadores do direito (juízes, advogados, promotores, etc.) não aceitar os resultados do perfil genético automaticamente como se fosse prova irrefutável, bem como apresentar rigor e fundamentação na valoração dessa perícia, necessariamente, em conjunto com as demais provas e indícios do caso concreto.

Nesse sentido, Casabona e Malanda 22 alertam que muitas vezes a coincidência do perfil do suspeito com o perfil da cena do crime pode sugerir apenas que o suspeito esteve presente na cena do crime (e, em algumas ocasiões, nem mesmo isso pode ser concluído, pois os vestígios podem ter sido transferidos de um lugar a outro - intencionalmente, por descuido ou mesmo por casualidade). Os autores esclarecem, por exemplo, que:

(...) aunque del informe se derive que el semen encontrado en la cavidad vaginal de la mujer que denuncia una violación se corresponde con el ADN del sospechoso, ello únicamente nos informará, en su caso, de que ha existido una relación sexual, pero no de que ésta se haya producido $\sin$ el consentimiento de la presunta víctima. Esto último requerirá realizar otras investigaciones probatorias.

Por ello, un resultado positivo en el análisis de ADN no puede servir, por un lado, para establecer una conexión irrefutable entre el vestigio biológico y el sospechoso; y por otra parte, tampoco afirmar la culpabilidad del mismo. Sin embargo, un resultado negativo sí podría llevar a la absolución pese a la existencia de indicios de culpabilidad.

Por fim, é preciso dar especial atenção à denominada cadeia de custódia ${ }^{23}$ como forma de garantia da fiabilidade, segurança e credibilidade da informação genética levada a termo em laudo pericial. Sem tais garantias toda e qualquer informação proveniente da pesquisa genética e do laudo pericial

22 CASABONA, Carlos Maria Romeo; MALANDA, Sergio Romeo. Los Identificadores del ADN en el Sistema de Justicia Penal. P. 43.

23 Sobre as garantias relacionadas à fiabilidade técnica e licitude, além de aspectos referentes ao conteúdo do informe pericial, recomenda-se a leitura de María José Cabezudo Bajo (2011 e 2012). 
carecerão de qualquer valor jurídico probatório. A incolumidade da cadeia de custódia é fundamental para assegurar a adequação e a transparência das técnicas utilizadas, bem como o estado das amostras coletadas e armazenadas. Na verdade, a referida cadeia de custódia serviria ainda para assegurar a adequada identificação, coleta, conservação, verificação e custódia da amostra de DNA, desde a sua obtenção até que se incorpore definitivamente no processo como meio de prova.

Nesse âmbito é que se sugere a harmonização das normas referentes aos procedimentos uniformes com aquelas reconhecidas em âmbito internacional, de modo que haja efetivo controle dos procedimentos técnicos e científicos e a possibilidade de contraperícia. No Reino Unido, por exemplo, existe regulamentação ${ }^{24}$ detalhada e rigorosa que determina, dentre outras questões, que as mostras devem ser lacradas e etiquetadas na frente do doador, a temperatura de conservação da amostra e o prazo de entrega em 48h. Além disso, dispõe que o laboratório não deve aceitar as amostras que sejam entregues em condições insatisfatórias, ou seja, sem a devida identificação ou cuja consistência seja motivo de suspeita.

Além dos aspectos anteriormente tratados, é fundamental enfrentar concretamente questões como: a) os critérios de inserção, manutenção e exclusão tanto dos perfis extraídos e analisados, quanto das amostras coletadas; b) os requisitos para que não haja anulação pelo Poder Judiciário da prova produzida caso não observe os direitos e as garantias constitucionalmente reconhecidos; $\mathbf{c}$ ) a eventual necessidade de que a coleta da amostra genética seja realizada com o acompanhamento de um advogado; assim como, d) a possibilidade de utilizá-la para a apuração de outros delitos (prova emprestada).

Uma lei que estipule tamanha mudança na forma de investigação e identificação criminal deve vir acompanhada de estudos aprofundados sobre o assunto, por meio de estudos de caso, análises de constitucionalidade em relação ao mérito, das formas como colocar esses novos procedimentos em prática, dos benefícios e dos prejuízos por eles trazidos, da segurança e da garantia que deve envolver os materiais coletados, tudo isso para que não se tenha mais uma lei sem utilidade prática e que não satisfaça às necessidades, ou pior, que agrida os direitos dos cidadãos e os princípios ditados pela Constituição Federal brasileira. Por isso, é preciso que se leve em consideração, invariavelmente, os postulados processuais penais - fundados nos postulados constitucionais - de modo que se compreenda o Direito Processual Penal não apenas como instrumento do Direito Penal, mas como mecanismo concretizador das promessas constitucionais.

\section{REFERÊNCIAS}

BARRETTO, Vicente de Paulo; SCHIOCCHET, Taysa. Bioética: dimensões biopolíticas e perspectivas normativas. In: STRECK, L.L.; ROCHA, L.S. Anuário do Programa de Pós-Graduação em Direito - UNISINOS. Porto Alegre: Livraria do Advogado, 2005.

BARROSO, Luís Roberto. Curso de direito constitucional contemporâneo: os conceitos fundamentais e a construção do novo modelo. 3. ed. São Paulo: Saraiva, 2011.

BELLIVIER, F.; NOIVILLE, C. Les biobanques. Paris: PUF, 2009.

CABEZUDO BAJO, María José. Valoración del sistema de protección del dato de ADN en el ámbito europeo. Revista General de Derecho Europeo, no 25, octubre 2011.

. La regulación del "uso forense de la tecnología del ADN" en España y en la UE: identificación de cinco nuevas cuestiones controvertidas. Revista General de Derecho Procesal, no 26, enero 2012.

CASABONA, Carlos Maria Romeo; MALANDA, Sergio Romeo. Los Identificadores del ADN en el Sistema de Justicia Penal, Revista Derecho y Proceso Penal. n²3, Arazandi, 2010.

JACQUES, Guilherme Silveira; MINERVINO, Aline Costa. Aspectos éticos e legais dos bancos de dados de perfis genéticos. Revista Pericia Federal, Brasília. Junho/2007-agosto/2008, ano IX, n 26, p. 17-20. Disponível em: http://www.apcf.org.br/Portals/0/revistas/downloads/26.pdf.

LIMA, Hélio Buchmuller. DNA x criminalidade. Revista Pericia Federal, Brasília. Junho/2007-agosto/2008, ano IX, n²6, p. 8-11. Disponível em: http://www.apcf.org.br/Portals/0/revistas/downloads/26.pdf

24 Circular do Ministério do Interior sobre o Banco Nacional de DNA (Homme Office Circular $n^{\circ}$ 16/1995). 
MELIÁ, Manuel Cancio. Terrorism and criminal Law: the dream of prevention, the nightmare of the rule of Law. New Criminal Law Review. Califórnia. vol. 14, No. 1, 2011, p. 108-122.

OCDE. Creation and governance of Human Genetic Research Databases. Disponível em: http:// www.oecd.org/document/50/0,2340,en_2649_34537_3 7646258_1_1_1_1,00.html Acesso em: $17 / 03 / 2009$.

SCHIOCCHET, Taysa. A utilização de teste genéticos no contexto médico: implicações jurídicas e normatização na órbita internacional e brasileira. In: FACHIN, Luiz Edson. et. al. (orgs.). Apontamentos críticos para o Direito Civil Brasileiro Contemporâneo II: Anais do Projeto de Pesquisa Virada de Copérnico. Curitiba: Juruá, 2009, p. 354 et. seq.

O humano entre o direito e a genética: pressupostos para o debate legislativo acerca das implicações jurídicas concernentes à criação de bancos de perfis genéticos para fins de persecução criminal. In: CALLEGARI, André Luís; STRECK, Lenio Luiz; ROCHA, Leonel Severo. (Org.). Constituição, sistemas sociais e hermenêutica: anuário do Programa de Pós-Graduação em Direito da Unisinos: mestrado e doutorado. Constituição, sistemas sociais e hermenêutica: anuário do Programa de Pós-Graduação em Direito da Unisinos: mestrado e doutorado. Porto Alegre: Livraria do Advogado, 2011, v. 8, p. 285-302.

UNITED NATIONS EDUCATIONAL, SCIENTIFIC AND CULTURAL ORGANIZATION (UNESCO). Declaração internacional sobre dados genéticos humanos. Paris: Unesco, 2003. Disponível em: <http://portal. unesco.org/shs/en/files/9193/11387255151DECLARATION_PORTUGAL.pdf/DECLARATION\%2BPORTUGAL. pdf $>$. Acesso em: 2 set. 2009. 